\title{
Flow experience in game based learning - a systematic literature review
}

\author{
Arttu Perttula, Kristian Kiili, Antero Lindstedt, Pauliina Tuomi \\ Tampere University of Technology \\ \{arttu.perttula, kristian.kiili, antero.lindstedt, pauliina.tuomi\}@tut.fi
}

\begin{abstract}
The entertaining elements implemented in a serious game are key factors in determining whether a player will be engaged in a play-learn process and able to achieve the desired learning outcomes. Thus, optimization of subjective playing experience is a crucial part of a game design process. Flow theory can be adopted for measuring user experience and analyzing the quality of serious game designs. In addition, flow seems to have a positive influence on performance enhancement, learning and engagement. The focus of this review is especially on examining the meaning of flow in the context of serious games as well as exploring the relationship between flow and learning, factors that influence occurrence of flow and how flow is operationalized. The review revealed that there are mainly conceptual considerations about flow in serious games, but no robust empirical evidence about the meaning of flow. This is in line with other studies. We argue that research on flow should focus on the specific aspects related to the very nature of serious games that combine enjoyment and learning. Furthermore, new methods to measure flow and analyse the data need to be developed and studied.
\end{abstract}

Keywords: Flow, Serious game, Learning, Engagement, Enjoyment, Literature review;

\section{Introduction}

Positive psychology emerged around the turn of the millennium [1]. It emphasizes the positive qualities of life like happiness, fulfillment and optimal experience [2]. Such qualities are important for all activities of human kind, including game playing. The enjoyment level that a serious game offers is a key factor in determining whether the player will be engaged in the gameplay, enjoy the playing and achieve the objectives of the game. Thus, the ability to quantify the playing experience and ability to identify what game elements engage players is important goal for both industry and academia. In general, game developers need a reliable way to measure the overall engagement level of their games to pinpoint specific areas of the experience that need improvement [3]. Several constructs have been proposed to describe playing experience, but definitional agreement has not been achieved [4]. Common concepts that have been linked to playing experience are engagement, involvement, immersion, presence, motivation and flow. The concept of flow is one of the most popular constructs used to describe the playing experience [3] and positive qualities of life. In fact, Kiili [5] has argued that games are most successful and engaging if they can produce flow experiences.

Csikszentmihalyi [6] introduced the flow state through the study of people involved in activities such as rock climbing, chess and dance. Subsequently flow theory has been applied in several different domains including, for example sports, art, work, human-computer interaction, games and education [7]. Flow describes a state of complete absorption or engagement in a specific activity in which a person excludes all irrelevant emotions and thoughts [8]. During the optimal experience, a person is in a positive psychological state where he or she is so involved with the goal-driven activity that nothing else seems to matter. An activity that produces such experiences is so pleasant that the person may be willing to do something without being concerned what he will get out of his action. This kind of intrinsic motivation is very important especially in serious games that usually require different cognitive or physical investments compared to entertainment games.

Csikszentmihalyi [9] has distinguished nine flow dimensions that constitute flow experience. These dimensions can be divided into flow conditions and flow characteristics [1]. Flow conditions 
are prerequisites of flow and they are referred also as antecedents of flow. Flow conditions include challenge-skill balance, clear goals, and unambiguous or immediate feedback dimensions. A perceived skill and challenge levels can be identified as the central precondition of flow experience [10] (figure 1). Flow characteristics describe the feelings of an individual when experiencing flow. Flow characteristics include sense of control, action awareness merging, loss of self-consciousness, concentration, time distortion and autotelic experience dimensions. On the other hand, it has been argued that the combination of the first eight dimensions of flow leads to flow that is characterised as an autotelic experience ( $9^{\text {th }}$ dimension). Autotelic experience refers to enjoyable and intrinsically rewarding experiences. The literature shows that flow researches have not achieved a definitional agreement about the deviation of the dimensions into conditions and characteristics. In spite of that Csikszentmihalyi [8] has argued that whenever people reflect on their flow experiences, they mention some, and often all the nine flow dimensions.

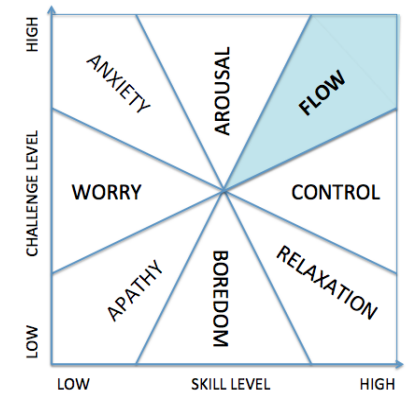

Figure 1. Mental state in terms of challenge and skill levels according to Csikszentmihalyi [11]

The empirical research on flow in serious games has emerged quite recently (e.g. [5, 12]). Since then flow term has been associated with enjoyable playing experience. Nevertheless, the flow research in serious games context is fragmented and this literature review aims to combine the findings and explore what is really known about flow experience in serious games. The focus of this review is especially on understanding the meaning of flow in serious games context, exploring the relationship between flow and learning, exploring factors that influence occurrence of flow and exploring how flow is operationalized. The following section presents the related work applied to flow in games in general. Next sections (3,4 and 5) concentrate on the application of flow theory findings to serious games. Section three describes the research questions in more detail and describes the process of the conducted literature review. In section four, the findings of the reviewed studies are summarized. Finally, research elaborates on the identified gaps and recommendations for future research are provided.

\section{Related work}

Game designers do not usually refer directly to the flow experience, but they certainly consider similar factors contributing to the flow experience. For example, Lehtimäki [13] referred to zone experience when describing games holding power. The concept being in the zone is commonly used in flow-related sports studies [14, 15]. Rollings and Adams [16] referred to a Zen-like state when discussing the phenomenon called Tetris trance. During this state, players seem to lose track of time and concentrate on the entire playing area as a whole.

Empirical findings of flow experience in games reveal that flow is one of the sources of longtime attractiveness for players (e.g. [17]). Hsu and $\mathrm{Lu} \mathrm{[18]} \mathrm{have} \mathrm{applied} \mathrm{a} \mathrm{technology} \mathrm{acceptance}$ model that incorporates social influences and flow experience as a construct to predict peoples' acceptance of online games. Flow experience was identified to be one of the major predictors of intention to play games in the future. In addition, good usability of the game interface was found to be a critical perquisite of flow experience. According to Kiili \& Lainema [19] playability is a notion that incorporates the relevant aspects of both flow and usability. Weibel et al. [20] have reported that a human-controlled opponent generates higher flow experience than a computer-controlled opponent. According to their study, flow mediates the relationship between presence and enjoyment.

Researchers have developed models about flow experience in game context. For example, Sweetser and Wyeth [21] constructed a GameFlow model for evaluating enjoyment in games. The GameFlow model consists of concentration, challenge, skills, control, clear goals, feedback, immersion, and social interaction elements, each including a set of criteria for achieving enjoyment 
in games. In the context of educational games Kiili [5] proposed an experiential gaming model that is based on experiential learning theory, flow theory and game design. In Kiili's model the flow theory is used as a framework to facilitate positive user experience in order to maximize the impact of educational games. In addition, Kiili et al. [4] have proposed a flow framework for education games that aim to facilitate the analysis of educational games and to provide design-support for game developers.

Until now several different methods have been used to study flow experience from which selfreporting techniques have been the most common methods [22]. The most popular flow scales that are utilized particularly in sports are Flow State Scale-2 (FSS-2) and Dispositional Flow Scale-2 (DFS-2) [23]. Theses scales are based on the original dimensions of flow proposed by Csikszentmihalyi [8]. However, Procci et al. [3] found that the refinement of the DFS-2 scale in game context is needed. Additionally, scales for measuring subjective playing experience have been developed. For example, Brockmyer et al. [24] developed the Game Engagement Questionnaire (GEQ) that includes a subscale for flow as well as subscales for presence, absorption, and immersion. However, in game experience questionnaires the flow dimension is often inadequately present and it is not based on the views of Csikszentmihalyi.

Furthermore, new methods to study flow are emerging. Advances in neurosciences are making it possible to continuously monitor the player status [25, 26]. Certain dimensions of flow can be validated with functional brain imaging, which can improve the understanding of human emotions and motivational processes during media entertainment [27]. The combination of subjective and objective measurements can increase the explained variance of player experiences such as flow, immersion and engagement [25, 28]. Berta et al. [29] have defined a map of the neurophysiological activities in correspondence with different levels of a player's flow.

\section{Method}

The systematic review aims to collect, evaluate and interpret all the available research evidence relevant to the defined research questions. This section describes the approach that was used to conduct this systematic review.

\subsection{Research objectives and questions}

This research considers the meaning of flow theory in serious games focusing on game based learning. The overall aims are to study to what extent flow theory can be used as a design framework for serious games involving educational objectives and as a game quality measure. The following research questions were formed to focus on empirical evidence and to limit the research context:

RQ1: How flow is operationalized in game based learning context and how it is measured?

RQ2: To what extent can flow be used as a serious games quality measure?

RQ3: What empirical evidence exists about the influence of certain game elements and mechanics on flow experience?

RQ4: What empirical evidence exists about the meaning of each flow dimension on the level of experienced flow?

RQ5: What empirical evidence exists about the influence of flow experience on effectiveness of game based learning?

RQ6: What empirical evidence exists about the influence of player characteristics on the level of experienced flow?

\subsection{Outline of the review process}

To ensure that the review was conducted systematically, we carried out the following steps:

1. Defining objectives: We defined the research questions and research terms.

2. Scoping the review: We developed explicit inclusion criteria for determining, which studies will be included in the review.

3. Searching for studies: We used defined research terms to collect relevant papers for the review.

4. Screening studies: Each article that the search phase returned was screened against the inclusion criteria. The inclusion of articles into the review was made transparent by appraising each study against the same inclusion criteria. 
5. Describing and mapping: We outlined the methodology and findings from each included study and coded the studies according to the created coding schema. The coding schema was formed according to the research questions.

6. Quality and relevance appraisal: We evaluated each study in terms of used flow measurements, sample size of the study, transparency of the research method, and significance of the findings. The study was excluded if flow operationalization did not correspond at all to the current view of flow, if the sample size was smaller than fifteen, or if the research methods were not appropriately described.

7. Synthesizing study findings: Based on the mappings, quality and relevance appraisal of the studies, we synthesized findings under thematic headings and the weight of evidence was evaluated.

8. Conclusions and recommendations: We identified research gaps and formed a set of recommendations for further research.

\subsection{Searching and screening papers}

In this case, the development of a search strategy was an iterative process. First we performed several preliminary searches to achieve an overview of the literature in order to define the final search terms for the literature review. The preliminary search results indicated that it is hard to define search terms that return a great body of existing research papers about the theme of the review. Thus, the selected search terms were left quite open (* substitutes zero or more characters), which resulted in search that returned a lot of papers that did not actually contribute to defined research questions (more details in the section 3.2). The search terms were applied to title, abstract and keywords of the paper. The search terms used were:

"flow" AND

"educational game*" OR "edutainment game*" OR "serious game*" OR "simulation game*" OR "games-based learning" OR "games based learning" OR "game based learning" OR "game-based learning" OR "working memory game*" OR "learning game*" OR "math game*" OR "mathematics game*" OR "problem solving game*".

Papers were searched from Science Direct, Scopus, and Web of Science databases that were selected based on accessibility and relevance to the theme of the review. The search process was finalized on June 20, 2014. The search returned altogether 144 papers. When duplicates were removed the amount of potential papers were reduced to 118 . Table 1 describes the inclusion criteria that were defined to select the appropriate papers. Using these five conditions, 24 papers that met the inclusion criteria were defined as relevant to the review and underwent the mapping and quality appraisal phases described below (see sections 3.4 and 3.5). Others were excluded.

Table 1. Inclusion criteria for the review.

\begin{tabular}{l|l}
\hline Criterion type & \multicolumn{1}{c}{ Inclusion criteria } \\
\hline Topic & $\begin{array}{l}\text { Paper must relate to serious games designed for learning purposes and address at } \\
\text { least one of the research questions. }\end{array}$ \\
\hline Publication date & Paper must be published between 2004 -2014 (end of May). \\
\hline Publication type & Publication must be a journal article. \\
\hline Research type & Results about flow must be based upon empirical research. \\
\hline Transparency & $\begin{array}{l}\text { The methodology upon which the study is based must be made explicit (especially } \\
\text { measurement of flow experience). }\end{array}$ \\
\hline
\end{tabular}

\subsection{Mapping selected studies}

We familiarized with the studies of the selected papers and coded the studies according to the created coding schema (simplified version presented in table 2). The coding schema was created in accordance with research questions RQ1-RQ6. 
Table 2. Coding schema.

\begin{tabular}{l|l}
\hline Question & Description of the code \\
\hline RQ1 & $\begin{array}{l}\text { Qualitative / Quantitative / Mixed methods } \\
\text { Original flow dimensions / Modified flow dimensions } \\
\text { Flow scale created / Flow scale adopted } \\
\text { Reliability of flow scale analyzed } \\
\text { Flow dimension means calculated }\end{array}$ \\
\hline RQ2 & Flow used as a game quality measure \\
\hline RQ3 & $\begin{array}{l}\text { Mechanic }+/-/ 0 \\
\text { Aesthetics }+/-/ 0 \\
\text { Story }+/-/ 0 \\
\text { Technology }+/-/ 0\end{array}$ \\
\hline RQ4 & $\begin{array}{l}\text { Importance of flow dimensions addressed } \\
\text { Engagement }+/-/ 0\end{array}$ \\
\hline RQ5 & $\begin{array}{l}\text { Gender }+/-/ 0 \\
\text { Previous playing experience }+/-/ 0 \\
\text { Previous knowledge }+/-/ 0 \text { (about game content) }\end{array}$ \\
\hline
\end{tabular}

Note: Code+ refers to a positive effect; Code- refers to a negative effect; Code0 means that effect is measured, but the effect was not significant.

\subsection{Quality and relevance appraisal}

We evaluated the extent that each study contributed to the research questions defined in this review. Additionally, the weight of evidence was judged based on the methodological quality and relevance of used methodologies. If the study did not meet the quality and relevance standards for the review, it was excluded from the review. Based on quality and relevance appraisal, five studies were excluded. Therefore, only 19 studies were included in the final review.

\subsection{Synthesizing study findings}

We used thematic synthesis technique because it works well when synthesizing findings of multiple multidisciplinary research studies [30, 31]. Thematic synthesis includes three stages: 1) the free lineby-line coding of the findings of primary studies, 2) the organization of these free codes into related areas to construct descriptive themes, and 3) the development of analytical themes. However, these themes overlap to some degree. The first stage was described in Mapping of selected studies section. In this way, findings were translated into a common metric and thus it was possible to compare and contrast them. In the second stage, the extracted codes were used to identify descriptive themes that appeared in studies. A theme (finding) was labeled as strong evidence if several studies supported it. A finding was labeled as reasonable evidence if only few studies supported it. A finding was labeled as controversial evidence if the results of studies were controversial. Furthermore, quantitative data of different studies were synthesized and descriptive statistics were used to describe the results. Finally, more detailed analytical themes were formed and based on them conclusions of the state of art of flow in serious games was evaluated and recommendations for future research were formed.

\section{Findings}

19 papers were finally included in this systematic review. These studies covered a total population of 1775 study participants. All the papers did not report the amount of females and males separately. Anyway, both genders are well represented generally. Age range varied typically from middle school to university students. Only five of these nineteen studies used mixed method approach bringing together data collected with questionnaire(s), observations as well as interviews. On the contrary, fifteen studies used solely quantitative questionnaires to gather the flow data. Studies present flow research from six countries: 9 from Taiwan, 4 from Finland, 3 from United States, 1 from Czech Republic, 1 from Germany and 1 from Israel (figure 2). 


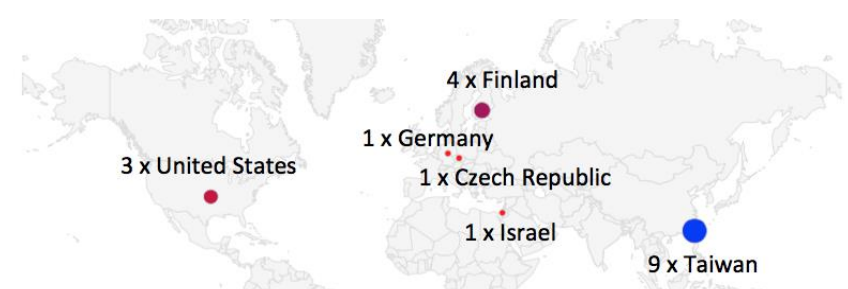

Figure 2. Geographical locations of analyzed studies

There was not a consistent way to be found to measure the flow experience among the papers. Some of them utilized a custom-made or a modified questionnaire and others adopted questionnaires used in previous research. In addition to the flow, all studies measured and tackled also other aspects such as different pedagogical approaches, usability issues and other user experience aspects that complicated the analysis and synthesis of findings. As it may be assumed, papers involved different kinds of games, from a mobile augmented reality game to a desktop simulation game. Thus, also aims and purposes of games varied a lot. However, all of them were serious games with educational objectives or software platforms that were used in an educational purpose in this case. A couple of games were utilized in two separate publications (mainly the same authors, but with a slightly different topic). Table 3 presents a summary of the participants, method/design, and games used in each study.

Table 3. Summary of the participants, methods and games used in each study.

\begin{tabular}{|c|c|c|c|}
\hline Study & Ps & Method/design & Game \\
\hline $\begin{array}{l}\text { \#1 } \\
\text { Barzilai } \\
\text { \& Blau } \\
{[32]}\end{array}$ & $\begin{array}{l}\mathrm{N}=182 \\
(111 \mathrm{f} \\
71 \mathrm{~m}) \\
\text { age: } 6-14\end{array}$ & $\begin{array}{l}\text { The study was conducted in a pretest- } \\
\text { posttest control group experimental design. } \\
\text { A control group that only played the game, } \\
\text { a group that studied with an online scaffold } \\
\text { and then played the game, and a group that } \\
\text { played the game and then studied with an } \\
\text { online scaffold. }\end{array}$ & $\begin{array}{l}\text { Shakshouka Restaurant is an } \\
\text { online game and a business } \\
\text { simulation in which players } \\
\text { explore the concepts of cost, } \\
\text { price, and profit by running a } \\
\text { restaurant. }\end{array}$ \\
\hline $\begin{array}{l}\# 2 \\
\text { Bressler } \\
\text { \& } \\
\text { Bodzin } \\
{[33]}\end{array}$ & $\begin{array}{l}\mathrm{N}=68 \\
(33 \mathrm{f}, 35 \\
\mathrm{m}), \text { age: } \\
11-15\end{array}$ & $\begin{array}{l}\text { Employed a mixed methods approach and } \\
\text { used a convergent design with the data- } \\
\text { validation variant. Data sources included: } \\
\text { pre- and post-surveys, field observations } \\
\text { and group interviews. The survey data were } \\
\text { collected online. }\end{array}$ & $\begin{array}{l}\text { School Scene Investigators: The } \\
\text { Case of the Stolen Score Sheets is } \\
\text { a vision-based AR science } \\
\text { learning game played inside the } \\
\text { school environment with Quick } \\
\text { Response codes. }\end{array}$ \\
\hline $\begin{array}{l}\# 3 \\
\text { Brom et } \\
\text { al. } \\
{[34]}\end{array}$ & $\begin{array}{l}\mathrm{N}=75 \\
\text { age: } 18- \\
31\end{array}$ & $\begin{array}{l}\text { To measure flow when interacting with the } \\
\text { simulation, the Flow Short Scale is } \\
\text { administered. To obtain information about } \\
\text { participants' affective state, PANAS is } \\
\text { utilized. Retention and Transfer tests done } \\
\text { during a pilot study. One motivation } \\
\text { questionnaire administered immediately } \\
\text { after the treatment and one a month after as } \\
\text { well as the test of graphing skills. }\end{array}$ & $\begin{array}{l}\text { The educational simulation } \\
\text { (unnamed) that models the } \\
\text { brewing process. }\end{array}$ \\
\hline $\begin{array}{l}\# 4 \\
\text { Faiola et } \\
\text { al. } \\
{[35]}\end{array}$ & $\begin{array}{l}\mathrm{N}=115 \\
(68 \mathrm{f}, 47 \\
\mathrm{m}), \text { age: } \\
18-65\end{array}$ & $\begin{array}{l}\text { The online questionnaire based on } \\
\text { information gathered from formative } \\
\text { research on flow, gaming, and virtual } \\
\text { reality, as well as exploratory questions } \\
\text { about the relationship between online } \\
\text { virtual communities, flow, and } \\
\text { telepresence. }\end{array}$ & $\begin{array}{l}\text { Second Life is a 3D virtual world } \\
\text { that can be used as a virtual } \\
\text { learning environment or } \\
\text { simulation. }\end{array}$ \\
\hline $\begin{array}{l}\# 5 \\
\text { Fu et al. } \\
{[36]}\end{array}$ & $\begin{array}{l}\mathrm{N}=166 \\
\text { age: } \\
\text { university } \\
\text { students }\end{array}$ & $\begin{array}{l}\text { The scale, named EGameFlow, was } \\
\text { developed. Four learning games were used } \\
\text { as the instruments of scale verification. } \\
\text { Survey questionnaires were distributed to } \\
\text { the study participants. Five validity tests } \\
\text { were applied to observe content validity, } \\
\text { construction validity, criterion-related } \\
\text { validity, convergent validity, and divergent } \\
\text { validity. }\end{array}$ & $\begin{array}{l}\text { The motherboard-assembly } \\
\text { pairing game helps to remember } \\
\text { computer components. The game } \\
\text { describing computer parts guides } \\
\text { to understand computer } \\
\text { accessories. The hands-on OS } \\
\text { game deals with problems } \\
\text { associated with an operating } \\
\text { system. The bear-cub's computer } \\
\text { game introduces a wide range of } \\
\text { computer software. }\end{array}$ \\
\hline
\end{tabular}




\begin{tabular}{|c|c|c|c|}
\hline $\begin{array}{l}\text { \#6 } \\
\text { Hong et } \\
\text { al. } \\
{[37]}\end{array}$ & $\begin{array}{l}\mathrm{N}=209 \\
(105 \mathrm{f} \\
104 \mathrm{~m}) \\
\text { age: } 5- \\
\text { 6th } \\
\text { graders }\end{array}$ & $\begin{array}{l}\text { The study implemented Pearce's et al. } \\
\text { (2005) flow definition as measurement for } \\
\text { the engagement to the game. The factor } \\
\text { loading and reliability were testified } \\
\text { through confirmatory factor analysis. }\end{array}$ & $\begin{array}{l}\text { Two games about San Zi Jing (a } \\
\text { Chinese educational poem). } \\
\text { Games were based on Solitary and } \\
\text { Heart Attack games that are the } \\
\text { most popular card games among } \\
\text { Taiwan elementary school } \\
\text { students. }\end{array}$ \\
\hline $\begin{array}{l}\# 7 \\
\text { Hou \& } \\
\text { Li } \\
{[38]}\end{array}$ & $\begin{array}{l}\mathrm{N}=67 \\
(50 \mathrm{f}, 17 \\
\mathrm{m}), \text { age: } \\
18-53\end{array}$ & $\begin{array}{l}\text { After students had played the game, they } \\
\text { completed the computer assembly } \\
\text { knowledge test, a questionnaire that } \\
\text { measured their game acceptance and their } \\
\text { evaluations of game elements, and the } \\
\text { Flow Scale for Games. }\end{array}$ & $\begin{array}{l}\text { In Boom Room, students must } \\
\text { collect hardware and assemble a } \\
\text { desktop computer to disable a } \\
\text { bomb and escape a room within } \\
10 \text { min. The game promotes } \\
\text { students' learning through } \\
\text { problem-solving process. }\end{array}$ \\
\hline $\begin{array}{l}\# 8 \\
\text { Hsiao et } \\
\text { al. } \\
{[39]}\end{array}$ & $\begin{array}{l}\mathrm{N}=51 \\
\text { age: } 5 \text { th } \\
\text { graders }\end{array}$ & $\begin{array}{l}\text { Creativity is measured using the Creativity } \\
\text { Assessment Packet (CAP) scale provided } \\
\text { by Lin and Wang (1994). The study } \\
\text { recorded the overall activity (observations). } \\
\text { The questionnaire adopted the EGameFlow } \\
\text { scale. }\end{array}$ & $\begin{array}{l}\text { The ToES is a virtual learning } \\
\text { environment with tasks involving } \\
\text { imaginative and creative thinking, } \\
\text { as well as related knowledge of } \\
\text { electricity. Tasks are solved by } \\
\text { collaborating and discussing with } \\
\text { other players. }\end{array}$ \\
\hline $\begin{array}{l}\# 9 \\
\text { Hsieh et } \\
\text { al. } \\
{[40]}\end{array}$ & $\begin{array}{l}\mathrm{N}=34 \\
(17 \mathrm{f}, 17 \\
\mathrm{m}), \text { age: } \\
\text { 4-6th } \\
\text { graders }\end{array}$ & $\begin{array}{l}\text { After the game play sessions, all students } \\
\text { completed a flow experience questionnaire } \\
\text { that was developed by Kiili (2006). }\end{array}$ & $\begin{array}{l}\text { Happy Black-faced Spoonbill is a } \\
\text { resource classification game. A } \\
\text { player is a bird that has to } \\
\text { correctly classify a resource to a } \\
\text { corresponding resource bin for } \\
\text { environmental protection. }\end{array}$ \\
\hline $\begin{array}{l}\# 10 \\
\text { Kiili } \\
{[5]}\end{array}$ & $\begin{array}{l}\mathrm{N}=18(3 \\
\mathrm{f}, 15 \mathrm{~m}) \\
\text { age: } \\
\text { university } \\
\text { students }\end{array}$ & $\begin{array}{l}\text { Activities were observed virtually and } \\
\text { recorded on Web-logs. A questionnaire was } \\
\text { employed to measure players' experiences. } \\
\text { The flow antecedents included in the } \\
\text { experiential gaming model were measured } \\
\text { with questions based on a questionnaire on } \\
\text { the flow construct in online environments. } \\
\text { Post-test consisted of lecture, game and } \\
\text { flow questions. Finally, the participants } \\
\text { were interviewed in groups. }\end{array}$ & $\begin{array}{l}\text { In IT-Emperor university level } \\
\text { students work in a production } \\
\text { company as trainees. Players are } \\
\text { hired to produce learning material } \\
\text { about usability. The content of the } \\
\text { game reflects the problems and } \\
\text { issues that could arise in a } \\
\text { production company. }\end{array}$ \\
\hline $\begin{array}{l}\# 11 \\
\text { Kiili et } \\
\text { al. } \\
\text { [7] }\end{array}$ & $\begin{array}{l}\mathrm{N}=98 \\
(81 \mathrm{f}, 17 \\
\mathrm{m}), \text { age: } \\
\text { majority } \\
\text { under } 25\end{array}$ & $\begin{array}{l}\text { Five groups played the simulation game } \\
\text { twice. The data related to flow was } \\
\text { gathered with a 9-item questionnaire } \\
\text { developed by the authors. }\end{array}$ & $\begin{array}{l}\text { Realgame is a collaborative } \\
\text { business simulation game that is } \\
\text { designed to give players a realistic } \\
\text { view of business processes } \\
\text { through case-based learning. }\end{array}$ \\
\hline $\begin{array}{l}\# 12 \\
\text { Kiili \& } \\
\text { Lainema } \\
{[19]}\end{array}$ & $\begin{array}{l}\mathrm{N}=92 \\
(41 \mathrm{f}, 51 \\
\mathrm{m}), \text { age: } \\
20-30\end{array}$ & $\begin{array}{l}\text { The study operationalized the dimensions } \\
\text { of flow experience in an educational game } \\
\text { context and tested a constructed GameFlow } \\
\text { questionnaire. }\end{array}$ & $\begin{array}{l}\text { Realgame is a collaborative } \\
\text { business simulation game that is } \\
\text { designed to give players a realistic } \\
\text { view of business processes } \\
\text { through case-based learning. }\end{array}$ \\
\hline $\begin{array}{l}\# 13 \\
\text { Li et al. } \\
{[41]}\end{array}$ & $\begin{array}{l}\mathrm{N}=117 \\
(16 \mathrm{f}, 101 \\
\text { m), age: } \\
\text { 1st year } \\
\text { eng. } \\
\text { school } \\
\text { students }\end{array}$ & $\begin{array}{l}\text { The study used the learning experience } \\
\text { survey to obtain flow states. The Motivated } \\
\text { Strategies for Learning Questionnaire was } \\
\text { used to evaluate motivation. }\end{array}$ & $\begin{array}{l}\text { Train } B \& P \text { is a simulation } \\
\text { environment that aims to help } \\
\text { novice programmers learn } \\
\text { algorithmic thinking skills } \\
\text { including object-oriented } \\
\text { concepts, conditions, iteration and } \\
\text { object communication. }\end{array}$ \\
\hline $\begin{array}{l}\# 14 \\
\text { Linek et } \\
\text { al. } \\
{[42]}\end{array}$ & $\begin{array}{l}\mathrm{N}=59 \\
(21 \mathrm{f}, 38 \\
\mathrm{m}), \text { avg. } \\
\text { age } 13.6 \\
\text { years }\end{array}$ & $\begin{array}{l}\text { To assess the extent of intrinsic motivation } \\
\text { the short version of the multidimensional } \\
\text { Intrinsic Motivation Inventory is utilized. } \\
\text { The degree of flow an individual } \\
\text { experienced was assessed by means of the } \\
\text { translated version of the short flow-scale. }\end{array}$ & $\begin{array}{l}\text { As experimental environment a } \\
\text { first chapter of an educational } \\
\text { adventure game (unnamed) } \\
\text { regarding optics (properties of } \\
\text { light) was designed. The learning } \\
\text { contents about the properties of } \\
\text { light were directly integrated in } \\
\text { the story of the game. }\end{array}$ \\
\hline
\end{tabular}




\begin{tabular}{|c|c|c|c|}
\hline $\begin{array}{l}\# 15 \\
\text { Liu et al. } \\
{[43]}\end{array}$ & $\begin{array}{l}\mathrm{N}=117 \\
\text { age: } 1 \text { st } \\
\text { year } \\
\text { university } \\
\text { students }\end{array}$ & $\begin{array}{l}\text { The study used the learning experience } \\
\text { survey to obtain flow states. The Motivated } \\
\text { Strategies for Learning Questionnaire was } \\
\text { used to evaluate motivation. }\end{array}$ & $\begin{array}{l}\text { Train } B \& P \text { is a simulation } \\
\text { environment that aims to help } \\
\text { novice programmers learn } \\
\text { algorithmic thinking skills } \\
\text { including object-oriented } \\
\text { concepts, conditions, iteration and } \\
\text { object communication. }\end{array}$ \\
\hline $\begin{array}{l}\# 16 \\
\text { Liu } \\
{[44]}\end{array}$ & $\begin{array}{l}\mathrm{N}=110, \\
\mathrm{~N} 1=55 \\
(11 \mathrm{f}, 44 \\
\mathrm{m}), \mathrm{N} 2= \\
55(9 \mathrm{f}, \\
46 \mathrm{~m}), \\
\text { age: } 20- \\
21\end{array}$ & $\begin{array}{l}\text { The group } 1 \text { was instructed using the } \\
\text { gaming method and the group } 2 \text { was } \\
\text { instructed using the non-gaming method. } \\
\text { During the study, tests, a survey, and } \\
\text { interviews were conducted. A multimedia } \\
\text { flow scale was developed based on the } \\
\text { Flow State Scale. }\end{array}$ & $\begin{array}{l}\text { Star Chef is an educational game } \\
\text { for learning algorithms (stack, } \\
\text { queue, data list, tree traversal, } \\
\text { binary search tree). }\end{array}$ \\
\hline $\begin{array}{l}\# 17 \\
\text { Ma \& } \\
\text { Williams } \\
{[45]}\end{array}$ & $\begin{array}{l}\mathrm{N}=20, \\
\text { age: } 5- \\
\text { 8th } \\
\text { graders }\end{array}$ & $\begin{array}{l}\text { A GameFlow questionnaire was adopted to } \\
\text { examine flow in the game. A narrative } \\
\text { immersion survey designed to measure } \\
\text { player immersion. Includes also } \\
\text { observations and follow-up interviews. }\end{array}$ & $\begin{array}{l}\text { Conquest of Coastlands (CoC) is } \\
\text { an educational adventure game } \\
\text { that includes multiple quests. The } \\
\text { Ecosystem in Peril quest is a life } \\
\text { and environmental science lesson } \\
\text { for children aged 11-13. }\end{array}$ \\
\hline $\begin{array}{l}\# 18 \\
\text { Oksanen } \\
{[46]}\end{array}$ & $\begin{array}{l}\mathrm{N}=62 \\
\text { students, } \\
24 \\
\text { teachers }\end{array}$ & $\begin{array}{l}\text { The participants' subjective game } \\
\text { experiences were gathered using Finnish } \\
\text { translated versions of the Game Experience } \\
\text { Questionnaire and Sociability Scale. }\end{array}$ & $\begin{array}{l}\text { Game Bridge (GB) is a } \\
\text { collaboratively scripted } \\
\text { multiplayer game with a focus on } \\
\text { task solving in the area of human } \\
\text { sustainability. }\end{array}$ \\
\hline $\begin{array}{l}\# 19 \\
\text { Wang \& } \\
\text { Chen } \\
{[47]}\end{array}$ & $\begin{array}{l}\mathrm{N}=115 \\
(59 \mathrm{f}, 56 \\
\text { m), age: } \\
\text { students }\end{array}$ & $\begin{array}{l}\text { The instruments utilized were the game } \\
\text { preference questionnaire, the game flow } \\
\text { experience and motivation questionnaire, } \\
\text { and the project grading rubrics. }\end{array}$ & $\begin{array}{l}\text { Two custom-made problem- } \\
\text { solving games for learning to } \\
\text { program: Matching game was } \\
\text { employed for concept } \\
\text { clarification. Challenging game } \\
\text { helps concept consolidation and } \\
\text { elaboration. }\end{array}$ \\
\hline
\end{tabular}

Citation counts of articles included in this systematic review (figure 3) were retrieved on January 12, 2017 from Science Direct, Scopus, and Web of Science databases (articles \#1 - \#19 were searched from the same databases - see section 3.3). 11 papers had over 10 citations. Two papers did not have indexed citations. The paper that presents EGameFlow scale [36] has been cited the most.

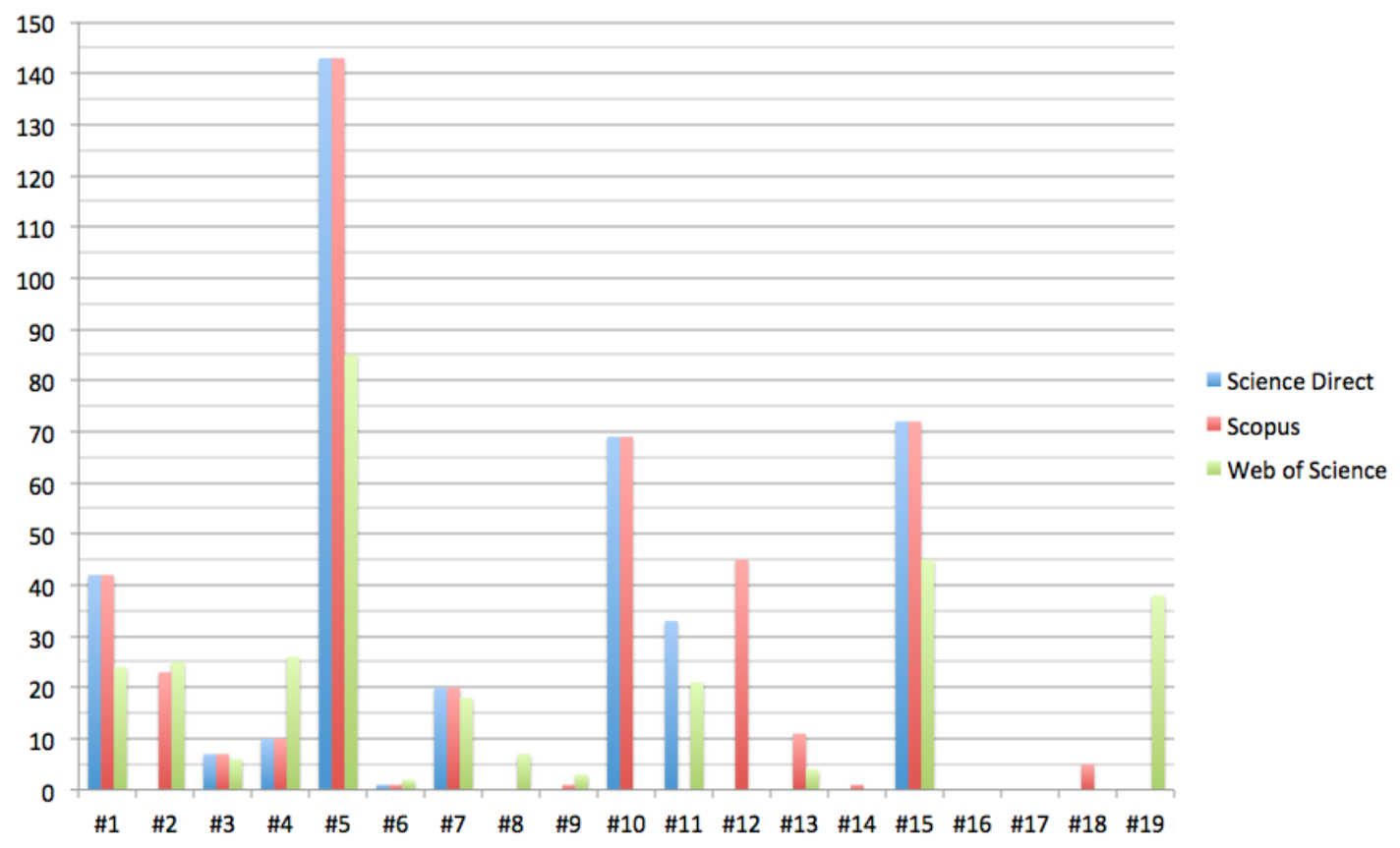

Figure 3. Citations according to analyzed studies (see table 3) 


\subsection{Quantitative measurement of flow}

Quantitative measures where used to explore flow experience in all studies. Several different flow scales were adopted or developed. We could not identify a certain scale that was the most popular. Flow Short Scale [48, 49] was used in two studies [34, 42]. Flow Short Scale includes all flow dimensions except unambiguous feedback and autotelic experience. Kiili and Lainema [19] developed GameFlow questionnaire that Ma et al. [45] also adopted. GameFlow questionnaire extends the original flow dimensions with story and gamefulness components. On the other hand, Hou and Li [38] as well as Hsieh et al. [40] measured flow with Flow Scale for Games [50], which includes all original flow dimensions. These scales operationalize flow dimensions differently, but the operationalization is still quite convergent. For example, action awareness merging dimension is operationalized as playability in GameFlow and Flow Scale for Games questionnaires. Table 4 summarizes the dimensions that were quantitatively measured in reviewed studies.

Table 4. Flow dimensions that were measured in reviewed studies.

\begin{tabular}{|c|c|c|c|c|c|c|c|c|c|c|c|c|c|c|c|c|c|c|c|}
\hline \multirow[b]{2}{*}{$\begin{array}{l}\text { Included flow } \\
\text { dimensions }\end{array}$} & \multicolumn{19}{|c|}{ Articles by reference numbers (see table 3 ) } \\
\hline & \# & $\begin{array}{l}\Xi \\
\sim \\
\#\end{array}$ & $\#$ & \# & \# & \# & \# & $\stackrel{\infty}{\#}$ & \# & $\begin{array}{l}\Xi \\
\#\end{array}$ & $\underset{\Xi}{\mathbb{Z}}$ & $\frac{m}{\#}$ & $\underset{\#}{ \pm}$ & $\frac{n}{\#}$ & $\frac{0}{\#}$ & 五 & $\begin{array}{l}\Xi \\
\infty \\
\#\end{array}$ & $\frac{\varrho}{\#}$ & $\%$ \\
\hline $\begin{array}{l}\text { Challenge-skill } \\
\text { balance }\end{array}$ & & $\mathbf{x}$ & $\mathbf{x}$ & $\mathbf{x}$ & $\mathbf{x}$ & & $\mathbf{x}$ & $\mathbf{x}$ & $\mathbf{x}$ & $\mathbf{x}$ & $\mathbf{X}$ & $\mathbf{X}$ & $\mathbf{X}$ & $\mathbf{X}$ & $\mathbf{x}$ & $\mathbf{X}$ & & $\mathbf{x}$ & 83 \\
\hline Clear goals & & $\mathbf{x}$ & $\mathbf{x}$ & & $\mathbf{x}$ & & $\mathbf{x}$ & $\mathbf{x}$ & $\mathbf{x}$ & $\mathbf{x}$ & $\mathbf{x}$ & & $\mathbf{x}$ & & $\mathbf{x}$ & $\mathbf{x}$ & & $\mathbf{x}$ & 67 \\
\hline $\begin{array}{l}\text { Unambiguous } \\
\text { feedback }\end{array}$ & & $\mathbf{x}$ & & & $\mathbf{x}$ & & $\mathbf{x}$ & $\mathbf{x}$ & $\mathbf{x}$ & $\mathbf{x}$ & $\mathbf{x}$ & & & & $\mathbf{x}$ & $\mathbf{x}$ & & $\mathbf{x}$ & 56 \\
\hline Concentration & $\mathrm{x}$ & $\mathrm{x}$ & $\mathrm{x}$ & $\mathrm{x}$ & $\mathrm{x}$ & $\mathrm{x}$ & $\mathrm{x}$ & $\mathrm{x}$ & $\mathrm{x}$ & $\mathrm{x}$ & $\mathrm{x}$ & & $\mathrm{x}$ & & $\mathrm{x}$ & $\mathrm{x}$ & $\mathrm{x}$ & $\mathrm{x}$ & 89 \\
\hline $\begin{array}{l}\text { Time distortion / } \\
\text { Immersion* }\end{array}$ & $\mathrm{X}$ & $\mathrm{X}$ & $\mathrm{X}$ & $\mathrm{X}$ & $\begin{array}{l}\mathrm{X} \\
*\end{array}$ & & $\mathrm{x}$ & $\begin{array}{l}\mathrm{X} \\
*\end{array}$ & $\mathrm{X}$ & $\mathrm{X}$ & $\mathrm{X}$ & & $\mathrm{X}$ & & $\begin{array}{l}\mathrm{X} \\
*\end{array}$ & $\mathrm{X}$ & $\mathrm{X}$ & $\mathrm{x}$ & 83 \\
\hline Sense of control & & $\mathrm{x}$ & $\mathrm{x}$ & $\mathrm{x}$ & $\mathrm{x}$ & $\mathrm{x}$ & $\mathrm{x}$ & $\mathrm{x}$ & $\mathrm{x}$ & $\mathrm{x}$ & $\mathrm{x}$ & & $\mathrm{x}$ & & $\mathrm{x}$ & $\mathrm{x}$ & & $\mathrm{x}$ & 78 \\
\hline $\begin{array}{l}\text { Action awareness } \\
\text { merging / } \\
\text { Playability* }\end{array}$ & & $\mathrm{X}$ & $\mathrm{X}$ & $\mathrm{X}$ & & & $\begin{array}{l}\mathrm{X} \\
*\end{array}$ & & $\begin{array}{l}\mathrm{X} \\
*\end{array}$ & $\begin{array}{l}\mathrm{X} \\
*\end{array}$ & $\begin{array}{l}\mathrm{X} \\
*\end{array}$ & & $\mathrm{X}$ & & & $\begin{array}{l}\mathrm{X} \\
*\end{array}$ & & $\begin{array}{l}\mathrm{X} \\
*\end{array}$ & 56 \\
\hline $\begin{array}{l}\text { Loss of self- } \\
\text { consciousness }\end{array}$ & & $\mathrm{X}$ & $\mathrm{X}$ & & & & $\mathrm{x}$ & & $\mathrm{x}$ & $\mathrm{X}$ & $\mathrm{X}$ & & $\mathrm{X}$ & & & $\mathrm{x}$ & & $\mathrm{X}$ & 56 \\
\hline $\begin{array}{l}\text { Autotelic } \\
\text { experience }\end{array}$ & & $\mathrm{x}$ & & & & & $\mathrm{x}$ & & $\mathrm{x}$ & $\mathrm{x}$ & $\mathrm{x}$ & & & & $\mathrm{x}$ & $\mathrm{x}$ & & $\mathrm{x}$ & 44 \\
\hline Story & & & & & & & & & & & $\mathrm{X}$ & & & & & $\mathrm{X}$ & & $\mathrm{X}$ & 17 \\
\hline Gamefulness & & & & & & & & & & & $\mathrm{X}$ & & & & & $\mathrm{X}$ & & $\mathrm{x}$ & 17 \\
\hline Social interaction & & & & & $\mathrm{x}$ & & & $\mathrm{x}$ & & & & & & & & & & & 11 \\
\hline $\begin{array}{l}\text { Knowledge } \\
\text { improvement }\end{array}$ & & & & & $\mathrm{X}$ & & & $\mathrm{x}$ & & & & & & & & & & & 11 \\
\hline $\begin{array}{l}\text { Playfulness or } \\
\text { enjoyment }\end{array}$ & & & & & & $\mathrm{x}$ & & & & & & & & & $\mathrm{x}$ & & & & 11 \\
\hline Being in the zone & & $\mathrm{x}$ & & & & & & & & & & & & & & & & & 6 \\
\hline Engagement & & & & $\mathrm{x}$ & & & & & & & & & & & & & & & 6 \\
\hline
\end{tabular}

Note: $m$ refers to a multiplayer game; * refers to the latter one of defined dimension names; First 9 areas refer to the original dimensions proposed by Csikszentmihalyi; Bolded dimensions refer to flow prerequisites.

In general, table 4 shows that the use of dimension varies quite a lot in the studies and only few new dimensions or components are proposed to extend flow. However, the domination of original flow dimensions can be clearly seen. The most often used dimensions are concentration (89\%), challenge-skill balance (83\%), time distortion (83\%) and sense of control (78\%). It is not surprising that challenge-skill balance is one of these, because it forms the core of flow experience and it is sometimes used even alone to measure flow (e.g. [41, 43]). The most rarely measured original flow dimension is autotelic experience $(44 \%)$. This is reasonable, because it has been argued that the combination of the first eight dimensions of flow leads to flow that is characterised as an autotelic experience $\left(9^{\text {th }}\right.$ dimension) and its measurement have been questioned [51]. The evidence that reviewed studies provide does not justify to extend flow with new dimensions proposed in some studies and more controlled research with bigger sample sizes are needed. Researchers should focus 
especially on social dimension of playing games, because playing is social in nature. In fact, for example Bakker et al. [52] has stated that flow can occur also at the team level and this dimension should be explored in multiplayer serious games. Two studies of the literature review that measured social interaction dimension utilized single player games in their study.

In each study, flow questionnaires were distributed after a gameplay session and none of the studies utilized Experience Sampling Method (ESM) that allows exploring flow patterns during a certain activity [51]. The post questionnaire approach may decrease the validity of flow measurement, because the meaning of last game events may affect too much on player's answers and distort the overall experience. On the other hand, also the use of ESM has been criticised, because randomly provided flow questionnaires may break down the flow state during the playing sessions and that way decrease the validity of the measurement [51]. In future, researchers should consider new and non-disturbing ways to adopt Experience Sampling Method approach in serious games research.

\subsection{Flow as a game quality measure}

In most of the reviewed studies flow was used to explore how engaging and enjoyable the game was. In other words, flow was used as a game quality measure in terms of engagement and enjoyment. Table 5 lists the mean values of flow experience in 14 studies that provided data to calculate it (transformed to 5-point Likert scale). The mean value of flow experience was $3.84(\mathrm{~N}=1150)$. This score is quite high if we take into account that most of the used game test beds were research prototypes and had their shortages. Furthermore, the overall flow score of the studies is almost equal when compared to flow level experienced in sports [23]. However, it is hard to validly interpret flow scores that are based on quantitative measurements. Did the players really achieve a flow state or not? For example, Swann et al.'s [1] review of flow experience in elite sports summarized that athletes commonly report experiencing approximately five of the dimensions at the time. Because achieving flow state does not require all flow dimensions to be present simultaneously, researchers should consider new ways to analyze dimension based flow data.

Table 5. Mean values of flow experience in reviewed studies.

\begin{tabular}{c|c|c|l}
\hline $\begin{array}{c}\text { Articles (see } \\
\text { table 3) }\end{array}$ & $\begin{array}{c}\text { Mean of flow in } \\
\text { 5-point Likert scale }\end{array}$ & $\begin{array}{c}\text { Original } \\
\text { Likert scale }\end{array}$ & $\mathbf{N}$ \\
\hline$\# \mathbf{1 0}$ & 3.30 & 6 & 182 \\
\hline$\# 3$ & 4.12 & 5 & 98 \\
\hline$\# 4$ & 4.03 & 7 & 75 \\
\hline$\# 5$ & 3.82 & 5 & 115 \\
\hline$\# \mathbf{\# 8}$ & 4.57 & 7 & 166 \\
\hline$\# 9$ & 3.79 & 5 & 67 \\
\hline$\# 11$ & 4.38 & 7 & 27 \\
\hline$\# 12$ & 3.73 & 5 & 34 \\
\hline$\# 14$ & 3.88 & 6 & 98 \\
\hline$\# 16$ & 3.67 & 5 & 92 \\
\hline$\# 17$ & 3.07 & 7 & 59 \\
\hline$\# 18$ & 3.84 & 5 & 55 \\
\hline
\end{tabular}

Table 6 shows mean values of flow dimensions (transformed to 5-point Likert scale) in reviewed studies in which means of dimensions were presented (articles \#6, \#10, \#13, \#15 and \#19 by reference numbers based on table 3 are excluded). From the table 6 we can see that mean values of flow dimensions vary between games. Naturally, the characteristics of games and users have affected this. However, only small variations can be found from overall dimension scores $(\mathrm{N}=565)$. Action awareness merging / playability dimension scored lowest $(\mathrm{M}=3.6)$ and clear goals highest $(\mathrm{M}=4.03)$. 
Table 6. Mean values of original flow dimensions in reviewed studies.

\begin{tabular}{|c|c|c|c|c|c|c|c|c|c|c|c|}
\hline \multirow[b]{2}{*}{ Dimensions } & \multicolumn{9}{|c|}{ Articles by reference numbers (see table 3 ) } & \multirow[b]{2}{*}{ M } & \multirow[b]{2}{*}{$\begin{array}{l}M \text { in } \\
\text { sports }\end{array}$} \\
\hline & $\begin{array}{l}\# 2 \\
\mathrm{~m}\end{array}$ & $\# 5$ & $\# 7$ & \#8 & $\# 9$ & $\begin{array}{l}\# 11 \\
\mathrm{~m}\end{array}$ & $\begin{array}{l}\# 12 \\
\mathrm{~m}\end{array}$ & $\# 16$ & $\# 17$ & & \\
\hline $\begin{array}{l}\text { Challenge-skill } \\
\text { balance }\end{array}$ & 4,22 & 3,55 & 3,79 & 4,39 & 4 & 4,05 & 3,66 & 3,73 & 3,72 & 3,90 & 3,7 \\
\hline Clear goals & 4,06 & 3,65 & 3,77 & 4,36 & 4,37 & 4,16 & 3,77 & $\mathbf{3 , 8}$ & 4,3 & 4,03 & 4,1 \\
\hline $\begin{array}{l}\text { Unambiguous } \\
\text { feedback }\end{array}$ & 4,12 & 3,71 & 3,85 & 4,3 & $3, \mathbf{8 3}$ & 3,72 & $\mathbf{3 , 4 3}$ & $\mathbf{3 , 8 3}$ & 4,22 & 3,89 & 3,9 \\
\hline Concentration & 4,37 & 3,79 & 3,91 & 4,33 & 3,64 & 3,77 & 3,75 & 3,83 & 3,78 & 3,91 & 3,65 \\
\hline Time distortion & 3,91 & 3,33 & 3,92 & 4,3 & 3,47 & 3,86 & 3,77 & 3,84 & 3,75 & 3,79 & 3,25 \\
\hline $\begin{array}{l}\text { Sense of } \\
\text { control }\end{array}$ & 4,18 & 3,56 & 3,89 & 4,5 & 3,63 & 4,31 & 3,57 & 3,68 & 4,03 & 3,93 & 3,65 \\
\hline $\begin{array}{l}\text { Action } \\
\text { awareness } \\
\text { merging / } \\
\text { playability * }\end{array}$ & 3,66 & & $\begin{array}{l}3.6 \\
*\end{array}$ & & $\begin{array}{l}3.54 \\
*\end{array}$ & $\begin{array}{l}3.54 \\
*\end{array}$ & $\begin{array}{l}3.81 \\
*\end{array}$ & & $\begin{array}{l}3.57 \\
*\end{array}$ & 3,62 & 3,65 \\
\hline $\begin{array}{l}\text { Loss of self- } \\
\text { consciousness }\end{array}$ & 3,65 & & 3,77 & & 3,89 & 3,75 & 4,01 & & 3,62 & 3,78 & 3,95 \\
\hline $\begin{array}{l}\text { Autotelic } \\
\text { experience }\end{array}$ & 4,62 & & 3,61 & & 4,18 & 3,74 & 3,8 & 3,84 & 3,78 & 3,94 & 3,98 \\
\hline
\end{tabular}

Note: values are transformed to 5-point Likert scale; $\mathrm{m}$ refers to a multiplayer game; * refers to the latter one of defined dimension names; Bolded dimensions refer to flow prerequisites.

The mean values of flow dimensions cannot be used to determine which of the flow dimensions are the most important in serious games context. However, mean values can be used as a quality measure of the game and to figure out which of the dimensions should be especially taken into account when iteratively improving a certain game design. In this ambition the flow prerequisites (challenge-skill balance, clear goals, and unambiguous feedback) are the most concrete and useful ones. For example, Wang \& Chen [47] found that progressive challenge and time pressure facilitated flow. Similarly, Kiili \& Lainema [19] stress the meaning of game mechanics that require continuous effort and time-intensity. Thus, game designers should pay more attention on challenge-skill balance and develop such adaptation models that facilitate achieving and maintaining flow experience. In addition to challenge-skill balance, background music [42], user generated game content [5] and social game mechanics [46] was found to facilitate flow experience. Nevertheless, the studies did not actually consider or study the meaning of certain game mechanics and thus recommendations about the usefulness of certain game mechanics cannot be created based on these findings.

In a couple of the studies the authors emphasized factors that disturb flow. For example, Ma and Prejean [45] found that technical problems and bad playability disturb flow. This can be a big problem in research that is based on game prototypes that are developed only for research purposes. When studying flow in serious games, researchers should ensure that the design of the game is good and all major technical problems are solved. Even small issues in interaction design and audiovisual implementation can affect on the outcomes of the research. On the other hand, flow can be used to measure also the quality of low fidelity game prototypes as well as a part of iterative game design process. However, if this is the case then the main aim of the research is not to study flow phenomenon, but to test the quality of the game in terms of flow. Furthermore, mechanics that enable dominative behavior in multiplayer games was found to disturb flow [19].

\subsection{Flow experience and learning}

Only five articles studied the relationship between flow experience and learning. In general, the articles provide some evidence that the flow experience has a positive influence on game based learning outcomes. In two studies the learning outcomes were measured with knowledge tests. For example, Liu [44] found a positive but non-significant correlation between flow and academic performance. The study showed that flow had a positive correlation also with enjoyment caused by the game. On the other hand, Kiili [5] found a strong connection between flow and learning. However, the sample size of this study was small $(\mathrm{n}=18)$ and thus the results are not generalizable. The results of studies in which learning was measured based on players' opinions support also the positive connection between flow and learning. Barzilai and Blau [32] showed that flow significantly predict learning. According to their structural equation model perceived learning was found to be a 
consequence of flow. Furthermore, the results of Kiili and Lainema [19] showed that there was a loose positive connection between flow experience and learning. One of the studies was only indirectly related to learning while learning was measured as players' feeling of divergent thinking as a part of creativity measurement [39]. In some cases, the success in the game could be used to describe learning. For example, Brom et al. [34] found that the high scoring players were more often in the flow state. Their study also revealed that flow correlated with motivation, which should facilitate learning. Although above findings support the positive relationship between flow and learning in serious games, more empirical research needs to be conducted before this relationship can be generalized.

\subsection{Flow and individual characteristics}

Two of the studies explored to what extent the age of players affects the level of experienced flow. Both studies found that higher age predicted higher flow [35, 40]. In Faiola et al.'s study [35] the age of players varied between 18 and $65(\mathrm{~N}=115)$. However, in Hsieh et al.'s study [40] the age differences between participants were very small $(\mathrm{N}=34)$. The participants were $4^{\text {th }}-6^{\text {th }}$ graders and thus it is possible that the way young children understood the abstract flow questions might have influenced on the results. Three of the studies explored the relationship between gender and flow. Two studies [33, 40] did not report any gender differences. Controversially, Hou and Li [19] found that men experienced higher flow than women in terms of flow antecedents (challenge-skill balance, clear goals, feedback, sense of control and playability). It is noteworthy that this result is based on quite small sample size $(\mathrm{N}=67)$ and the gender distribution is biased (male $=17$; female $=50$ ). Furthermore, the game that Hou and Li [19] used was about personal computer assembly, which may have appealed to men more than women. However, because the interest to subject matter was not measured we cannot be sure about the meaning of it on flow. On the other hand, Bressler and Bodzin [33] measured interest in subject matter and in their study it did not affect flow. Whereas they found that positive attitude to game playing predicted higher flow. Furthermore, the results of Hou and Li [38] indicate that also prior knowledge may influence positively on flow antecedents. As we can see, the results considering the meaning of player characteristics on flow are controversial and based on these findings any conclusions can not be formalized. More high quality research that focuses on player characteristics is needed.

\section{Conclusions and recommendations}

The research of flow in the field of serious games has started after the millennium. Whilst this review provides some evidence against the research questions RQ1-RQ6 (see section 3.1), surprisingly limited number of empirical studies on flow in serious games context was found. The relatively small amount of studies used in the review reflects the lack of empirical evidence about flow and indicates that conceptual considerations about flow in serious games is much more common than empirical research (in line with e.g. [53]). In fact, the review revealed that the state of art of flow research in serious games is at a low level.

The review showed that quantitative measurement of flow was the most common method to study flow in serious games (RQ1) and that flow can be used as a game quality measure in serious games context (RQ2). Several different flow scales were either adopted or developed and the original flow dimensions dominated the operationalization of flow. The controlled efforts to create new subscales that could more adequately address flow in serious games as well as more valid ways to measure flow during playing are needed. For example, researchers should develop new procedures to use Experience Sampling Method (ESM) based measurements in non-intrusive way. Such continuous flow data that is linked to time and game events could provide totally new insights about flow in serious games and produce also knowledge about the meaning of game mechanics in terms of flow (RQ3). Furthermore, because achieving flow state does not require all flow dimensions to be present simultaneously we should also consider new ways to analyze dimension based flow data (RQ4).

Nevertheless, the gathered evidence suggests that the flow has a positive influence on game based learning outcomes (RQ5). For example, Kiili [5] found a strong connection between flow and learning. However, the review shows that the meaning of individual characteristics and game mechanics has largely been neglected in the research (RQ6). Because flow is a subjective experience and game preferences vary a lot among people, studying the meaning of individual differences is a very important future goal in order to achieve better understanding of the flow phenomenon in 
serious games. This is to say, although the findings of the review provide some base line evidence about the importance of flow experience in serious games, more robust empirical research needs to be conducted before the results can be generalized.

To conclude, although we aimed to synthesize relevant findings from a wide range of literature, the evidence presented in this review may be incomplete. First, some studies may have been missed because of the used search criteria and databases. Second, the studies present flow research from small geographical areas that may affect the quality of findings. Third, in addition to the flow, all studies measured and tackled also other aspects such as different pedagogical approaches, usability issues and other user experience aspects that complicate the analysis and synthesis of findings. In practical terms, none of the studies was a pure flow study. Therefore, it was difficult to code the selected papers.

Bearing in mind the gathered findings and the limitations of this review following recommendations were formed:

- Further research in different serious game contexts is required in order to clearly establish the impact of flow in learning.

- Controlled research needs to be conducted to achieve a better understanding of flow in serious games and to be able to operationalize flow so that it more adequately addresses flow in serious games. To achieve this goal, engaging serious games should be used as test beds in which the users can really achieve flow state. In such context, it is possible to validly study the flow phenomenon and test possible extensions of flow.

- Research needs to be conducted to explore how different game mechanics influence the flow experience. Game events linked to players' flow data could produce knowledge about the game mechanics in terms of flow.

- More valid methods to measure flow during playing needs to be studied and developed. Because achieving flow state does not require all flow dimensions to be present simultaneously we should also consider new ways to analyze dimension based flow data collected with quantitative measures.

- Further research is needed to study the influence of subject matter interest, game genre and social aspects on flow.

\section{Acknowledgements}

This work has been co-funded by the EU under the FP7, in the Games and Learning Alliance (GALA) Network of Excellence, Grant Agreement nr. 258169 and by Academy of Finland (The Future of Learning, Knowledge and Skills programme).

\section{References}

[1] Swann, C., Keegan, R. J., Piggott, D., Crust, L., A systematic review of the experience, occurrence, and controllability of flow states in elite sport, Psychology of Sport and Exercise, 13(6), 807-819, 2012. https://doi.org/10.1016/j.psychsport.2012.05.006

[2] Seligman, M. E., Csikszentmihalyi, M., Positive psychology: An introduction (Vol. 55, No. 1, p. 5), American Psychological Association, 2000.

[3] Procci, K., Singer, A. R., Levy, K. R., Bowers, C., Measuring the flow experience of gamers: An evaluation of the DFS-2, Computers in Human Behavior, 2012. https://doi.org/10.1016/j.chb.2012.06.039

[4] Kiili, K., Lainema, T., Freitas, S. D., Arnab, S., Flow framework for analyzing the quality of educational games, Entertainment Computing, 2014. https://doi.org/10.1016/j.entcom.2014.08.002

[5] Kiili, K., Content creation challenges and flow experience in educational games: The ITEmperor case, The Internet and Higher Education, 8(3), 183-198, 2005. https://doi.org/10.1016/j.iheduc.2005.06.001

[6] Csikszentmihalyi, M., Beyond boredom and anxiety: Experiencing flow in work and play, Jossey-Bass, San Francisco, 1975.

[7] Kiili, K., de Freitas, S., Arnab, S., Lainema, T., The design principles for flow experience in educational games, Procedia Computer Science, 15, 78-91, 2012. https://doi.org/10.1016/j.procs.2012.10.060 
[8] Csikszentmihalyi, M., Flow: The Psychology of Optimal Experience, Harper Perennial, New York, 1991.

[9] Csikszentmihalyi, M., Flow: The psychology of optimal experience (2nd edition), NewYork: Harper \& Row, 2002.

[10] Keller, J., Landhäußer, A., The flow model revisited, In S. Engeser (Ed.), Advances in flow research (pp. 51-64), New York: Springer, 2012. https://doi.org/10.1007/978-1-4614-2359-1_3

[11] Csikszentmihalyi, M., Finding Flow, 1997.

[12] Lee, I., Kwon, H-J., Relations among flow, information processing strategies, and performance in a computer-based simulation game, ED-MEDIA 2005, 986-992, 2005.

[13] Lehtimäki, T., Zone kutsuu: eläytyminen tietokonepeleissä, Mikrobitti, 7/2005, 72-73, (In Finnish), 2005.

[14] Lewis, M.S., Cycling in the Zone, Athletic Insight, 1(3), Retrieved July 20, 2014, from http://www.athleticinsight.com/Vol1Iss3/Bicycle_Zone.htm, 1999.

[15] Krug, M., Playing in the zone. Athletic Insight, 1(3), Retrieved November 1, 2005, from http://www.athleticinsight.com/Vol1Iss3/Tennis_Zone.htm, 1999.

[16] Rollings, A. \& Adams, E., Andrew Rollings and Ernest Adams on Game design, USA: New Riders, 2003.

[17] Voiskounsky, A. E., Mitina, O. V., Avetisova, A. A., Playing Online Games: Flow Experience, PsychNology journal, 2(3), 259-281, 2004.

[18] Hsu, C. L., Lu, H. P., Why do people play on-line games? An extended TAM with social influences and flow experience, Information \& Management, 41(7), 853-868, 2004. https://doi.org/10.1016/j.im.2003.08.014

[19] Kiili, K., Lainema, T., Foundation for measuring engagement in educational games, Journal of Interactive Learning Research, 19(3), 469-488, 2008.

[20] Weibel, D., Wissmath, B., Habegger, S., Steiner, Y., Groner, R., Playing online games against computer-vs. human-controlled opponents: Effects on presence, flow, and enjoyment, $\begin{array}{llll}\text { Computers in } & \text { Human } & \text { Behavior,24(5), } & 2274-2291,\end{array}$ https://doi.org/10.1016/j.chb.2007.11.002

[21] Sweetser, P., Wyeth, P., GameFlow: a model for evaluating player enjoyment in games, Computers in Entertainment (CIE), 3(3), 3-3, 2005. https://doi.org/10.1145/1077246.1077253

[22] Weber, R., Tamborini, R., Westcott Baker, A., Kantor, B., Theorizing flow and media enjoyment as cognitive synchronization of attentional and reward networks, Communication Theory, 19(4), 397-422, 2009. https://doi.org/10.1111/j.1468-2885.2009.01352.x

[23] Jackson, S. A., Eklund, R. C., Assessing flow in physical activity: The flow state scale-2 and dispositional flow scale-2, Journal of Sport \& Exercise Psychology, 24, 133-150, 2002. https://doi.org/10.1123/jsep.24.2.133

[24] Brockmyer, J. H., Fox, C. M., Curtiss, K. A., McBroom, E., Burkhart, K. M., Pidruzny, J. N., The development of the Game Engagement Questionnaire: A measure of engagement in video game- playing, Journal of Experimental Social Psychology, 45(4), 624-634, 2009. https://doi.org/10.1016/j.jesp.2009.02.016

[25] Ninaus, M., Kober, S.E., Friedrich, E.V.C., Dunwell, I., deFreitas, S., Arnab, S., Ott, M., Kravcik, M., Lim, T., Louchart, S., Bellotti, F., Hannemann, A., Thin, A.G., Berta, R., Wood, G., Neuper, C., Neurophysiological methods for monitoring brain activity in serious games and virtual environments: a review, International Journal of Technology Enhanced Learning, Vol 6, Nr.1, pp. 78-103, 2014. https://doi.org/10.1504/IJTEL.2014.060022

[26] Plotnikov, A., Stakheika, N., De Gloria, A., Schatten, C., Bellotti, F., Berta, R., ... Ansovini, F., Exploiting real-time EEG analysis for assessing flow in games, In Advanced Learning Technologies (ICALT), IEEE, 2012.

[27] Klasen, M., Weber, R., Kircher, T. T., Mathiak, K. A., Mathiak, K., Neural contributions to flow experience during video game playing, Social cognitive and affective neuroscience, 2011.

[28] Nacke, L. E., Stellmach, S., Lindley, C. A., Electroencephalographic assessment of player experience: A pilot study in affective ludology, Simulation \& Gaming, 2010.

[29] Berta, R., Bellotti, F., De Gloria, A., Pranantha, D., Schatten, C., Electroencephalogram and physiological signal analysis for assessing flow in games, Computational Intelligence and AI in Games, IEEE Transactions on, 5(2), 164-175, 2013.

[30] James, T., Harden, A., Methods for the thematic synthesis of qualitative research in systematic reviews, BMC medical research methodology 8.1, 2008.

[31] James, T., Harden, A., Newman, M., Synthesis: combining results systematically and appropriately, 179-227 in Gough, David, Sandy Oliver, and James Thomas, An introduction to systematic reviews, Sage Publications, 2012. 
[32] Barzilai, S., Blau, I., Scaffolding game-based learning: Impact on learning achievements, perceived learning, and game experiences. Computers \& Education, 70, 65-79, 2014. https://doi.org/10.1016/j.compedu.2013.08.003

[33] Bressler, D. M., Bodzin, A. M., A mixed methods assessment of students' flow experiences during a mobile augmented reality science game, Journal of Computer Assisted Learning, 29(6), 505-517, 2013. https://doi.org/10.1111/jcal.12008

[34] Brom, C., Bromová, E., Děchtěrenko, F., Buchtová, M., Pergel, M., Personalized messages in a brewery educational simulation: Is the personalization principle less robust than previously thought?, Computers \& Education, 72, 339-366, 2014. https://doi.org/10.1016/j.compedu.2013.11.013

[35] Faiola, A., Newlon, C., Pfaff, M., Smyslova, O., Correlating the effects of flow and telepresence in virtual worlds: Enhancing our understanding of user behavior in game-based learning, Computers in Human Behavior, 29(3), 1113-1121, 2013. https://doi.org/10.1016/j.compedu.2013.11.013

[36] Fu, F. L., Su, R. C., Yu, S. C., EGameFlow: A scale to measure learners' enjoyment of e-learning $\begin{array}{lllll}\text { games, } \quad \text { Computers \& } \quad \text { Education, } & \text { 52(1), } & \text { 101-112, }\end{array}$ https://doi.org/10.1016/j.compedu.2008.07.004

[37] Hong, J. C., Hwang, M. Y., Chen, W. C., Lee, C. C., Lin, P. H., Chen, Y. L., Comparing the retention and flow experience in playing Solitary and Heart Attack games of San Zi Jing: A perspective of Dual Process Theory, Computers \& Education, 69, 369-376, 2013. https://doi.org/10.1016/j.compedu.2013.07.027

[38] Hou, H. T., Li, M. C., Evaluating multiple aspects of a digital educational problem-solvingbased adventure game, Computers in Human Behavior, 30, 29-38, 2014. https://doi.org/10.1016/j.chb.2013.07.052

[39] Hsiao, H. S., Chang, C. S., Lin, C. Y., Hu, P. M., Development of children's creativity and manual skills within digital game- based learning environment, Journal of Computer Assisted Learning, 2014. https://doi.org/10.1111/jcal.12057

[40] Hsieh, Y. H., Lin, Y. C., Hou, H. T., Exploring the role of flow experience, learning performance and potential behavior clusters in elementary students' game-based learning, Interactive Learning Environments, 1-16, 2013.

[41]Li, Z. Z., Cheng, Y. B., Liu, C. C., A constructionism framework for designing game like learning systems: Its effect on different learners, British Journal of Educational Technology, 44(2), 208-224, 2013. https://doi.org/10.1111/j.1467-8535.2012.01305.x

[42]Linek, S. B., Marte, B., Albert, D., Background Music in Educational Games: Motivational Appeal and Cognitive Impact, International Journal of Game-Based Learning (IJGBL), 1(3), 53-64, 2011. https://doi.org/10.4018/ijgbl.2011070104

[43] Liu, C.-C., Yuan-Bang, C., Chia-Wen, H., The effect of simulation games on the learning of computational problem solving, Computers \& Education 57.3, 1907-1918, 2011. https://doi.org/10.1016/j.compedu.2011.04.002

[44] Liu, T. Y., Using educational games and simulation software in a computer science course: learning achievements and student flow experiences, Interactive Learning Environments, 1-21, 2014.

[45] Ma, Y., Williams, D., Prejean, L., Designing an Electronic Educational Game to Facilitate Immersion and Flow, Journal of Interactive Learning Research, 25(1), 27-49, 2014.

[46] Oksanen, K., Subjective Experience and Sociability in a Collaborative Serious Game, Simulation \& Gaming, 1046878113513079, 2013. https://doi.org/10.1177/1046878113513079

[47] Wang, L. C., Chen, M. P., The effects of game strategy and preference-matching on flow experience and programming performance in game-based learning, Innovations in Education and Teaching International, 47(1), 39-52, 2010. https://doi.org/10.1080/14703290903525838

[48] Rheinberg, F., Vollmeyer, R., Engeser, S., Die Erfassung des Flow-Erlebens. In J. StiensmeierPelster \& F. Rheinberg, Diagnostik von Motivation und Selstkonzept (Tests und Trends N.F. 2). Göttingen: Hogrefe, 261-279, 2003.

[49] Engeser, S., Rheinberg, F., Flow, performance and moderators of challenge-skill balance, Motivation and Emotion, 32(3), 158-172, 2008. https://doi.org/10.1007/s11031-008-9102-4

[50] Kiili, K., Evaluations of an experiential gaming model, Human Technology, 2(2), 187-201, 2006. https://doi.org/10.17011/ht/urn.2006518

[51]Engeser, S., Advances in flow research, New York, NY: Springer, 2012. https://doi.org/10.1007/978-1-4614-2359-1 
pag. 72

[52] Bakker, A. B., Oerlemans, W., Demerouti, E., Slot, B. B., Ali, D. K., Flow and performance: A study among talented Dutch soccer players, Psychology of Sport and Exercise, 12(4), 442-450, 2011. https://doi.org/10.1016/j.psychsport.2011.02.003

[53] Bellotti, F., Kapralos, B., Lee, K., Moreno-Ger, P., Berta, R., Assessment in and of serious games: an overview, Advances in Human-Computer Interaction, 1, 2013. https://doi.org/10.1155/2013/136864 